Panel Title: Municipal Wireless Networks: Hot Spots for Mobile Business or Just Hot Air?

Panelists:

Dr. Andrew Clement

Professor

Faculty of Information Studies

University of Toronto

Toronto, Canada

Dr. Catherine Middleton*

Associate Professor

Faculty of Business

Ryerson University

Toronto, Canada

*Corresponding author

cmiddlet@ryerson.ca

(416) $979-5000$ x. 7923

\author{
Dr. Barbara Crow \\ Associate Professor \\ Communication Studies \\ York University \\ Toronto, Canada
}

Matthew Wong

Research Associate

Community Wireless Infrastructure Research

Project

Faculty of Information Studies

University of Toronto

Toronto, Canada

All the panelists are members of the Community Wireless Infrastructure Research Project (CWIRP) team (www.cwirp.ca). CWIRP is funded by Infrastructure Canada, to investigate the development and deployment of public ICT infrastructures. The project focuses on municipal and community wireless network initiatives.

\title{
Rationale for the Panel:
}

This panel investigates the business opportunities provided by municipal and community wireless network deployments. By Vos's (2007) estimate, there are close to 400 municipal networks, either deployed or in development in the United States. Many other municipal WiFi projects are being rolled out in cities around the world, including Toronto, London, Bologna, Singapore, Taipei and Perth. Developed by municipal governments, private providers or publicprivate partnerships, these networks are intended to serve the connectivity needs of local residents, tourists and business travellers, and provide a platform for the delivery of government, business and community services.

Municipalities are not the only organizations developing wireless network services. In North America, groups like CUWiN (Champaign-Urbana Community Wireless Network), Île Sans Fil (Montreal) and NYC Wireless (New York) have led the development of community based internet infrastructures, built by community members to provide access to the internet and to local resources.

It is widely believed that the deployment of wireless networks is beneficial for businesses. Municipal projects often start by deploying wireless infrastructure to the business core, providing internet connectivity to local businesses (often at more affordable rates than offered by incumbent internet service providers, e.g. e-Novations, 2005), and creating an environment where consumers can easily engage with these businesses over the internet. The provision of wireless networks is expected to attract businesses to communities, and spur economic 
development (Balhoff \& Rowe, 2005; The Wireless Philadelphia Executive Committee, 2005). As the City of Boston's Wireless Taskforce notes, there are "literally thousands of niche applications that local entrepreneurs and businesses will create if there is ubiquitous, open access to a wireless network" (Wireless Task Force, 2006, p. 7).

Although municipal wireless networks have been in the planning stages for several years, there are few networks that have been up and running for any length of time. As such, it is difficult to assess the extent to which wireless networks are providing value to businesses, governments and citizens. Some early evidence however suggests that network uptake has not been as strong as anticipated. For instance, in Taipei, Taiwan, the number of users of the city wide network dropped precipitously when a fee was instated for network usage (Belson, 2006). In other instances, plans for far-reaching networks have been scaled back (Gravelle, 2007), leaving a smaller network footprint that is less valuable for businesses looking for ubiquitous, city wide coverage.

Based on research conducted by the Community Wireless Infrastructure Research Project, this panel will investigate the business potential for wireless networks. We will discuss models that appear to be successful, while questioning the extent to which wireless networks are expected to provide value for consumers and businesses in the longer term.

Each panelist will make a short, opening statement, and outline questions about the overall value of municipal and community wireless networks. We will pose a series of questions to engage the audience in discussion about the value of WiFi to enable and facilitate mobile business applications.

\section{Andrew Clement: What are the Economic Prospects for Ubiquitous WiFi?}

Andrew will summarize claims arguing that ubiquitous WiFi can provide economic stimulation. Questions to be addressed include:

- Does mobile business need ubiquitous, cheap (wireless) internet access?

- Is this internet access best provided as a municipal or commercial telecom service?

- Are municipalities better off becoming businesses themselves in the WiFi arena (e.g. Toronto Hydro Telecom's OneZone network) or offering free/cheap ubiquitous service that fosters economic activity by a wide spectrum of 'real' businesses (e.g. the City of Fredericton's e-Zone)?

\section{Barbara Crow: Community Wireless, Small Business and Wireless Infrastructure}

Since 2003, Montreal's Île Sans Fil (ISF) has been providing wireless infrastructure for minimal costs, and by a largely volunteer group of highly skilled individuals, to a range of non-profit groups, individuals, and small businesses. To date, they have more than 120 free "hotspots" scattered throughout the city of Montreal.

Barbara will explore the unique community business model ISF has been developing to deploy and maintain "free" hotspots. ISF is interested in demonstrating both technically and politically, and in a transparent manner, how certain wireless technologies can be made readily available at minimal costs and delivered in meaningful ways via social software applications such as Wifidog and HAL. Moreover, as one of its founders commented:

[I]t's more the importance of having decentralizing players offering access; offering it wirelessly, not getting stopped by regulations or other non-business obstacles. (Benôit Gregoire, 
interview, June 7, 2006)

Overall, ISF has been tremendously successful in the development and deployment of community WiFi. They have set new standards for user integration through their social software applications and have been generous in transferring their skills and knowledge to other community WiFi groups around the world. But important questions remain:

- Do these social software applications make users more aware of community WiFi issues and community issues more generally?

- Can their model be replicated elsewhere? Does ISF provide a viable business model? How does it support mobility?

- Do hotspot providers and users care about how these services are being provided, and to whom?

- Can more than one business model provide WiFi in the small business and non-profit context?

\section{Matt Wong: Mesh Networking for Local Business Areas}

Matt will discuss the potential for mesh networks to provide connectivity to retailers within specific geographic locations. Drawing on his research with Wireless Nomad, a Toronto-based co-op wireless internet service provider, Matt will make an argument for alternative internet service providers. He will outline a model that provides small businesses with internet connectivity at rates that are much lower than the commercial internet service providers' business rates, yet still delivers adequate service. Questions to be addressed include:

- Is there demand for this sort of alternative business model?

- Will a mesh network option serve the needs of small businesses and their customers? How?

- Can mesh networks support mobile users? What applications would appeal to mobile users?

- How do small businesses use their internet connectivity to provide value to their customers?

Catherine Middleton: Why WiFi for Mobility?

Catherine will take the position that WiFi is not the right platform for mobile business application development. She will look at alternatives that offer better mobility, and argue that better devices and applications are needed to take advantage of WiFi as a platform for mobile business. This perspective raises various questions:

- Why invest in WiFi when mobile telephone networks already provide ubiquitous (or near ubiquitous) coverage?

- Is the laptop the right device for mobile business? Why not focus on the device that people already carry with them, the mobile phone?

- If there are limitations to mobile business applications on handheld devices, does a shift to WiFi offer new opportunities? What is needed to make WiFi a more appealing, user friendly platform for mobile business?

\section{Contribution}

The panel will offer participants insights into the advantages and disadvantages of WiFi networks as a platform for mobile business. We will discuss a variety of WiFi models, to 
highlight ways in which WiFi networks can support mobile business, and illustrate successful and not so successful business models for creating economic value through WiFi networks. We will challenge the idea that WiFi is universally useful for mobile business, showing how existing mobile networks can serve a wider audience with a user-friendly device that is already owned by many potential mobile business customers.

\section{Bibliography}

Balhoff, M. J., \& Rowe, R. C. (2005). Municipal Broadband - Digging beneath the Surface. Retrieved 27 April, 2007, from http://www.balhoffrowe.com/pdf/Municipal\%20Broadband-Digging\%20Beneath\%20the\%20Surface.pdf.

Belson, K. (2006, 26 June). What If They Built an Urban Wireless Network and Hardly Anyone Used It? New York Times, p. C1.

e-Novations. (2005). The Chronicles of E-Novation and Fred e-Zone. Fredericton.

Gravelle, S. (2007). Presentation to the Wireless Cities Summit. Retrieved 27 April, 2007, from http://www.thtelecom.ca/downloads/01-2407 Sharyn\%20Gravelle\%20Speech Wireless\%20Cities\%20Summit.pdf.

The Wireless Philadelphia Executive Committee. (2005). Wireless Philadelphia Business Plan: Wireless Broadband as the Foundation for a Digital City.

Vos, E. (2007). Muniwireless.com: 31 March 2007 List of US Cities and Regions. Retrieved 27 April, 2007, from http://www.muniwireless.com/reports/docs/March-312007summary.pdf.

Wireless Task Force. (2006). Wireless in Boston. Retrieved 30 August, 2006, from http://www.cityofboston.gov/wireless/Boston\%20Wireless\%20Task\%20Force\%20Repor t\%20-\%20Final.pdf. 